\title{
The STAT5 transcription factor in B-cells of patients with chronic lymphocytic leukemia
}

\author{
A. S. Matvieieva ${ }^{1}$, L. M. Kovalevska ${ }^{1}$, T. S. Ivanivska ${ }^{1}$, E. Klein ${ }^{2}$, E. V. Kashuba ${ }^{1,2}$ \\ ${ }^{1}$ R. E. Kavetsky Institute of Experimental Pathology, Oncology and Radiobiology, NAS of Ukraine \\ 45, Vasilkivska Str., Kyiv, Ukraine, 01022 \\ ${ }^{2}$ Karolinska Institutet \\ Stockholm SE-171 77, Sweden \\ Kashuba@nas.gov.ua,lenakash@yahoo.com
}

\begin{abstract}
Aim. To find out the cause of inhibition of the IL2-STAT5 signaling pathway in chronic lymphocytic leukemia (CLL) cells. Methods. CLL cells were isolated from peripheral blood, using gradient centrifugation on a ficoll-verografin mixture. Expression of the STAT1-6 genes at the mRNA level was analyzed, using the Oncomine database. Expression, phosphorylation status and cellular localization of the STAT5 protein were studied by fluorescence microscopy, using specific antibodies. Results. Unlike in B-cells of healthy donors, expression of the STAT5A protein was low in the patient CLL cells. As we have previously shown, the IL-2-STAT5 (JAK-STAT5) signaling pathway is inhibited in CLL cells. Now we demonstrated a low level of phosphorylation of the STAT5 protein, or a complete lack of phosphorylation in CLL cells. The STAT5A protein shows cytoplasmic localization, indicating the absence of complexes in the nucleus that activate/repress transcription of the STAT5-dependent genes. Conclusions. Inhibition of the IL-2-STAT5 pathway in CLL cells is caused by a lack of the STAT5 proteins phosphorylation and/or the absence of the active STAT5A transcription complexes in the nucleus of CLL cells.
\end{abstract}

Keyword s: Chronic lymphocytic leukemia (CLL), B-peripheral blood cells, STAT5, STAT5A, STAT5B, IL2-STAT5 signaling pathway.

\section{Introduction}

Chronic lymphocytic leukemia (CLL) [1] is one of the most common forms of leukemia in Europe and the United States. The incidence rate is approximately 3.5 per 100,000 population (5.0 for men and 2.5 for women) $[2,3]$. Prior to the onset of CLL, 5-10\% of patients develop monoclonal B cell lymphocytosis (MBL), when the number of B-lymphocytes in the peripheral blood counts $5 \cdot 10^{4}-2 \cdot 10^{6} / \mathrm{ml}$. MBL occurs in individuals over 40 . With a frequency of about $1 \%$ per year, MBL can progress to CLL, when the number of B cells is $5-10 \cdot 10^{6} / \mathrm{ml}$ [4].

(C) 2019 A. S. Matvieieva et al.; Published by the Institute of Molecular Biology and Genetics, NAS of Ukraine on behalf of Biopolymers and Cell. This is an Open Access article distributed under the terms of the Creative Commons Attribution License (http://creativecommons.org/licenses/by/4.0/), which permits unrestricted reuse, distribution, and reproduction in any medium, provided the original work is properly cited 
CLL develops due to the slow accumulation of the long-lived, but immunologically incompetent B-lymphocytes. Such cells are often referred to as "immuno-senescent", that describes their inability to differentiate into plasma cells, producing antibodies [4]. CLL cells do not proliferate, can not be activated by ligands and do not undergo apoptosis. Importantly, the transforming Epstein-Barr virus (EBV) could infect CLL cells, but infected cells do not proliferate even in vitro. It was shown, that one of the important viral proteins, i.e. LMP1, is not expressed in CLL cells $[5,6]$. Obviously, that several transcription factors, ATF-2/c-Jun, for example [5], are missing or not activated in CLL cells.

Of note, CLL cells express interleukin receptors (IL2R, IL4R, IL6R, IL10R, IL13R), TNF $\alpha$, interferon alpha (INFA) and gamma (INFG), and tumor growth factor beta (TGFB) [ 7].

The activation of the canonical TGFB pathway in B cells usually leads to induction of pro-apoptotic $B M F, B I M, B A X$ and, and as a consequence, to apoptosis [7]. In CLL cells, the level of $B C L 2$ does not differ from the expression of this gene in the peripheral blood B-cells of healthy individuals. TGFB receptors (TGFBRs) are expressed approximately equally in B-CLL and peripheral blood B-lymphocytes $[8,9]$. However, most of the genes that are usually induced by activation of the TGFB-SMAD2/3 pathway, namely BCL2L1 (BCL-XL), CCND2 (cyclin D2), ID1, $M Y C, A T F 3, T G I F 1$ andKLF10 (TIEG) are basically not expressed in CLL cells [9].

In the leukemic cells, the IL-2-STAT5 pathway is blocked [10]. The genes, usually induced by the homo (hetero) dimers of the STAT5 (Signal Transducer and Activator of
Transcription 5) proteins, namely $B C L 2 L 1$ (BCL-XL), CCND2 (cyclin D2), HIF1A, ID1, $M C L 1$ and $M Y C$, are barely detected. Previously, we have shown that the TGFBSMAD2/3 pathway is inhibited in CLL cells, due to retention of the SMAD3 and SMAD4 proteins in cytoplasm [11].Partially, the TGFBSMAD2/3 and IL-2-STAT5 pathways overlap. Anyway, both pathways are blocked in B-CLLcells.

In the present paper, the expression levels of the STAT1-6 genes, the phosphorylation status of the STAT5 protein and STAT5 cellular localization were studied in CLL cells and in the peripheral blood B-cells of healthy donors, with the aim to find a cause of inhibition of the IL-2-STAT5 pathways upon CLL.

\section{Materials and Methods}

The samples of the peripheral blood of 9 patients with CLL and one patient with B-cell prolymphocytic leukemia (BCPL) were obtained from the staff of the Department of Onco-hematology (headed by Professor D.F.Gluzman) at the R.E. Kavetsky Institute of Experimental Pathology, Oncology and Radiobiology (IEPOR) of National Academy of Sciences of Ukraine. In order to verify the CLL diagnosis, the immunocytochemical methods were used utilizing anti-alkaline phosphatase (APAAP) labeled streptavidin-biotin and alkaline phosphatase (LSAB-AP) and a wide panel of monoclonal antibodies. As a control, B-cells were isolated from peripheral blood of two healthy donors in the ficoll-verografin gradient. T cells were removed by forming rosettes with erythrocytes of sheep, followed by centrifugation. The experimental protocol was approved by a Committee on 
Bioethics at R.E. Kavetsky IEPOR of National Academy of Sciences of Ukraine.

The CLL cells were isolated from peripheral blood in the ficoll-verografin gradient. 50000 cells were attached to a glass slide for the further immune- fluorescent analysis.
Double staining of cells was performed, according to the following scheme: rabbit anti-phosphorylated STAT5 (recognizing both, STAT5A and STAT5B) (Cell Signaling, USA); secondary anti-rabbit antibodies produced in swine and conjugated with fluorescein-5-iso-
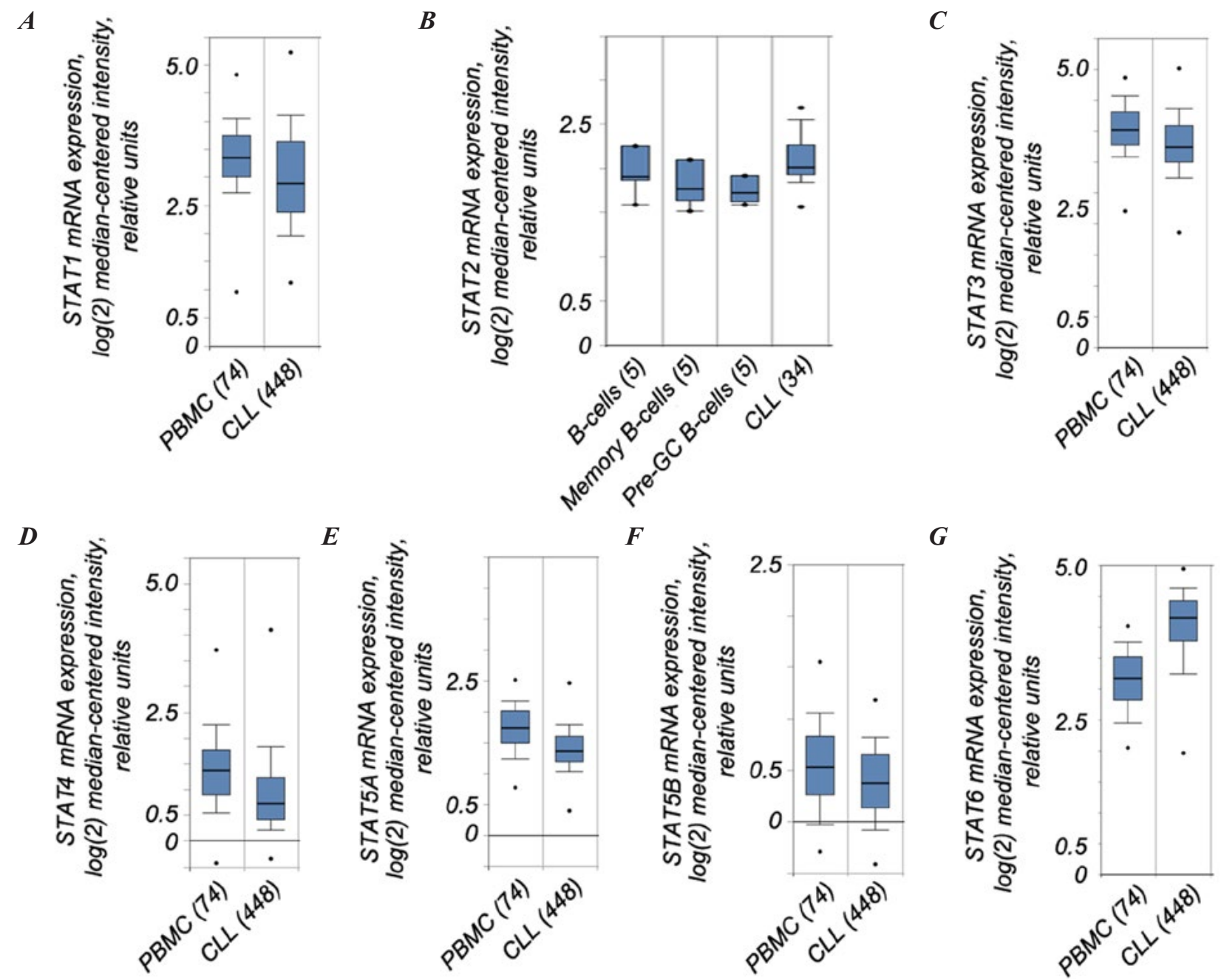

Fig. 1. A bioinformatic analysis of expression of STAT genes, using the Oncomine database. STAT2 (B), STAT5A (E) and $S T A T 5 B(F)$ genes are expressed at a lower level in peripheral blood mononuclear cells and in CLL cells, than STAT1 (A), STAT3 (C), STAT4 (D), and STAT6 (G). The lowest relative values are registered for STAT5B. The output data for STAT2 are published in a study [14], in which 8603 genes were analyzed. For other STAT genes, the initial analysis of 19574 genes is described in a work [15]. Conditions of the analysis: change of expression two-folds at least, only $5 \%$ of the best genes was chosen, $p=0.0067$. 

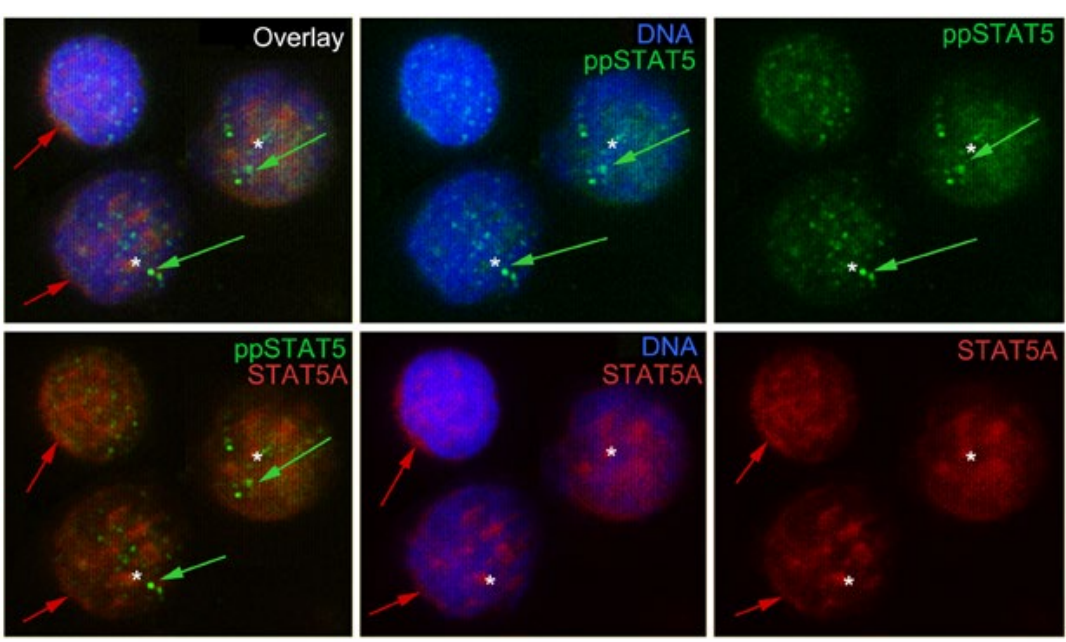

Fig. 2. Pattern of phosphorylation of STAT5 proteins (isoforms A and B) and their cellular localization. Phosphorylated form of proteins is shown in green. Red - a signal of the STAT5A protein. DNA is shown in blue. thiocyanate (FITC, DAKO, Denmark); then mouse monoclonal antibody against STAT5A (Cell Signaling, USA); and the secondary anti-mouse antibodies produced in horse and conjugated with Texas red (TR, DAKO, Denmark). The DNA was stained with Hoechst 3321 (Sigma-Aldrich, USA).

The images were captured by a CCD camera (Hamamatsu, Japan), assembled and analyzed in Photoshop.

To analyze the STAT gene expression at the mRNA level, a public database Oncomine was used. Oncomine contains the published data that was collected, standardized, annotated and statistically analyzed by Compendia Bioscience (www.oncomine.com, October 2018, Thermo Fisher Scientific, Ann-Arbor, MI, USA).

\section{Results and Discussion}

The bioinformatics analysis of the Oncomine database showed that the STAT genes at the mRNA level were expressed at approximately the same level in CLL cells, as in peripheral blood mononuclear cells (Fig. 1). Of note, the STAT2, STAT5A and STAT5B genes are ex- pressed at lower levels in peripheral blood mononuclear cells and in CLL cells, compared with the STAT1, 3, 4 and 6 genes. The lowest relative values of expression in CLL were shown for STAT5B. The obtained results confirm our previously published data [10, 12, 13].

Subsequently, the levels of phosphorylation of the STAT5 proteins (A and B isoforms) were assessed as well as the STAT5 cellular localization, using immunostaining. The control double staining (excluding one of the primary antibodies) did not show any background signals.

Noteworthy, the STAT5 protein (isoforms A and B) showed basal levels of phosphorylation in the control samples, i.e. B cells of healthy donors (Fig. 2, green signal). The phosphorylated protein was observed almost exclusively in the nucleus. Moreover, STAT5 formed large nuclear inclusions (indicated by green arrows in Fig. 2). The STAT5A protein was also localized mainly in the nucleus in B-cells of healthy donors (red signal in Figure 2), but a proportion of protein was observed in the cytoplasm as well (the red arrows in Fig. 2). Of note, the signals of phosphorylated STAT5 and STAT5A 
were partially co-localized in the nucleus (Fig. 2 , marked with asterisks), indicating activation of the IL-2-STAT5 (JAK-STAT5) pathway in $\mathrm{B}$ cells of healthy donors. Previously, the constitutively active STAT5 was found in the nucleus of rapidly proliferating malignant hematopoetic cells [16].

In contrast to the pattern observed in B-cells of healthy individuals, in CLL cells a very low signal of the phosphorylated STAT5 proteins was observed (Fig. 3, in green). The expression levels of the STAT5A protein were quite low as well (Fig. 3, red signal). Noteworthy, when the STAT5A signal was rather high, phosphorylation was not detected (Fig. 3, samples 102884 and 97570, in green). Moreover, the phosphorylated form was localized almost exclusively in the cytoplasm.

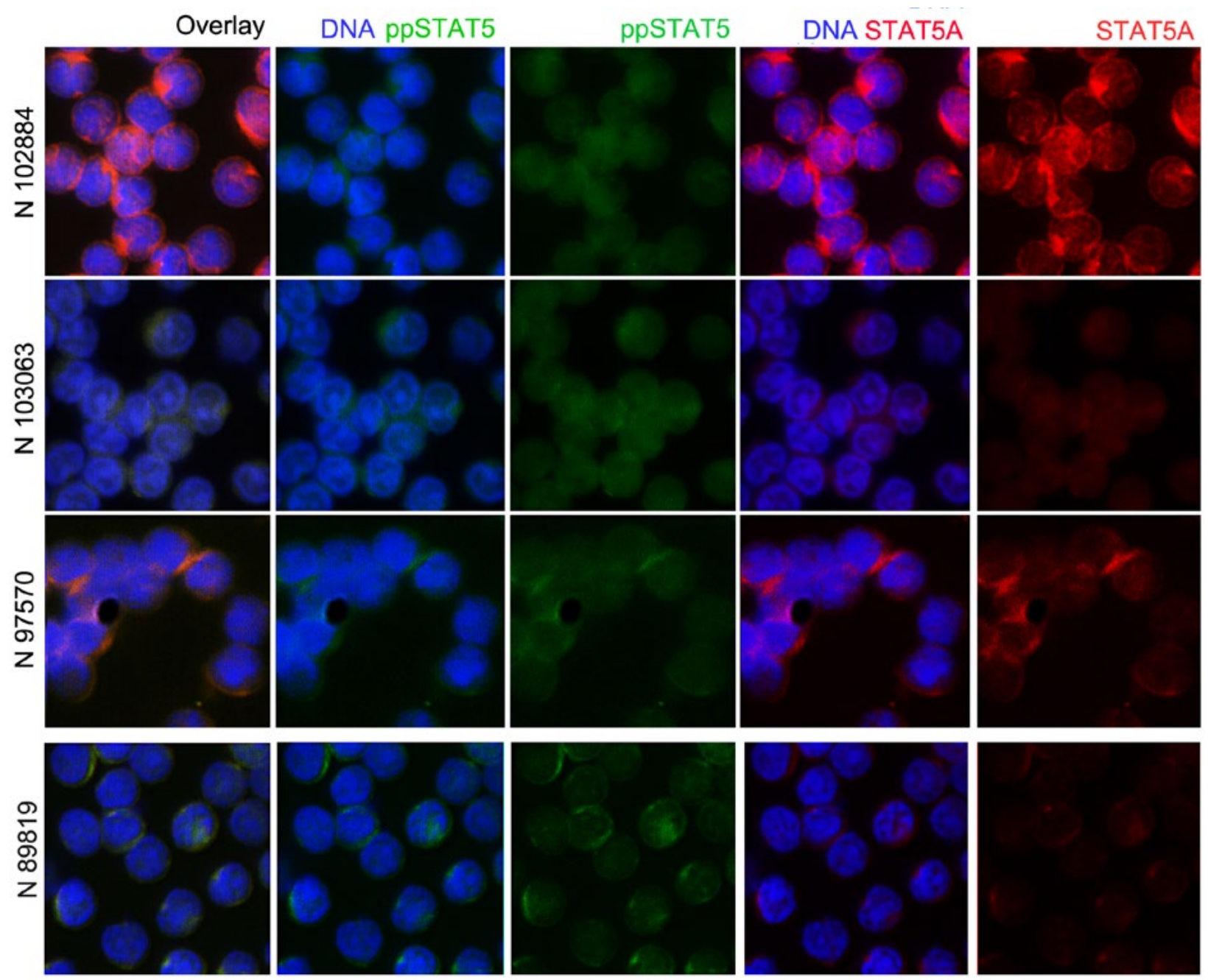

Fig. 3. Pattern of phosphorylation of STAT5 proteins (isoforms A and B) and their cellular localization in CLL cells. Phosphorylated form of proteins is shown in green. Red - a signal of the STAT5A protein. DNA is shown in blue. 

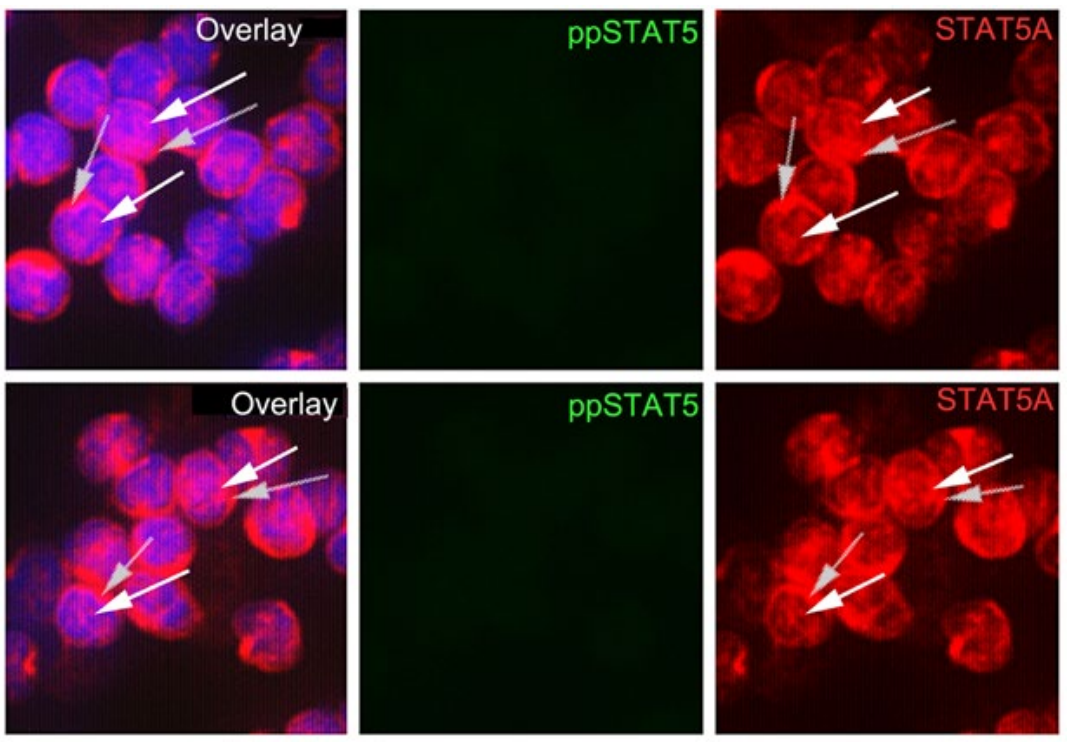

Fig. 4. Pattern of phosphorylation of STAT5 proteins (isoforms A and B) and their cellular localization in blood cells of BCPL patient. Phosphorylated form of proteins is shown in green. Red - a signal of the STAT5A protein. DNA is shown in blue.
In several patients the STAT5A protein was practically absent (Fig. 3, samples 103963 and 89819). Also, the expression levels of both isoforms could be very low (Fig. 3, sample 103063).

We have to emphasize that the STAT5A protein and the STAT5 phosphorylated isoforms were localized exclusively in the cytoplasm of peripheral blood mononuclear cells of CLL patients, in contrast to the pattern observed in B cells of healthy individual.

In B cell of the BCPL patient, the phosphorylated form of the STAT5 proteins was not detected. However, a high expression level of STAT5A was found, and a large proportion of the protein was localized in the nucleus (Fig. 4, red signal).

It is known, that the phosphorylated STAT5 proteins are activated constitutively in individuals with onco-hematological diseases [17-19].

The obtained results allow us to speculate that the inhibition of the IL-2-STAT5 (JAK-
STAT5) pathway in CLL cells might be due to the low levels of STAT5 phosphorylation, or the complete lack of the STAT5 phosphorylation. Noteworthy also, the STAT5A protein is found mainly in cytoplasm, which suggests that the protein complexes, activating transcription of the STAT5-depending genes are absent in the nucleus. It was demonstrated earlier that the STAT5 functions as transcription factor exclusively in the nucleus [20].

Actually, the reason for such cellular localization of the STAT5 proteins I CLL cells remains an open question. No doubt, that localization of proteins depends on their phosphorylation status. Moreover, activation of the JAK-STAT pathway is also regulated by the formation of homo(hetero)dimers of the various phosphorylated STAT proteins [21]. It is important, to study the phosphorylation status of other STAT proteins, namely, STAT2, 3 and 6 , and their cellular localization before and after the interaction of surface IL2R with the corresponding ligand (IL2) in CLL cells. 


\section{Conclusions}

As we have shown previously, the IL-2-STAT5 (JAK-STAT5) cellular signaling pathway is inhibited in CLL cells. In the present research we found a low level of the STAT5 phosphorylation, or even the complete absence of the phosphorylated protein in leukemic cells. The STAT5A protein is localized mainly in cytoplasm, indicating the absence of active transcriptional complexes in the nucleus, i.e. the STAT5 dependent genes are not induced.

\section{Acknowledgments}

We thank Professor Danilo F. Gluzman for a fruitful discussion and the critical reading of this manuscript. This work was supported by the National Academy of Science of Ukraine (grant 0116U007817) and Cancer Foundation (Sweden).

\section{REFERENCES}

1. * Muller-Hermelink HK ME, Catovsky D et al, editor. Cronic lymphocytic leukemia. small lymphocytic lymphoma. Lyon: IARC; 2008.

2. Jemal A, Siegel R, Xu J, Ward E. Cancer statistics, 2010. CA Cancer J Clin. 2010;60(5):277-300.

3. Gluzman DF, SklyarenkoLM, Nagornaya VA Diagnostic oncohematology. YEAR!!!!! Kiev: DIA; $256 \mathrm{p}$.

4. Scarfò L, Dagklis A, Scielzo C, Fazi C, Ghia P. CLL-like monoclonal B-cell lymphocytosis: are we all bound to have it? Semin Cancer Biol. 2010;20(6):384-90.

5. Bandobashi K, Liu A, Nagy N, Kis LL, Nishikawa J, Björkholm M, Klein G, Klein E. EBV infection induces expression of the transcription factors ATF2/c-Jun in B lymphocytes but not in B-CLL cells. Virus Genes. 2005;30(3):323-30.

6. Klein E, Nagy N. Restricted expression of EBV encoded proteins in in vitro infected CLL cells. Semin Cancer Biol. 2010;20(6):410-5.
7. Ravandi F, Talpaz M, Kantarjian H, Estrov Z. Cellular signalling pathways: new targets in leukaemia therapy. Br J Haematol. 2002;116(1):57-77.

8. Matvieieva AS, Kovalevska LM, Polishchuk OS, Mushtag M, Kashuba EV. Expression profile of transcription factors in the blood samples of patients with the chronic lymphocytic leukemia. Oncology. 2016; 18 (4): 311-5.

9. Matveeva A, Kovalevska L, Kholodnyuk I, Ivanivskaya T, Kashuba E. The TGF-beta - SMAD pathway is inactivated in cronic lymphocytic leukemia cells. Exp Oncol. 2017;39(4):286-290.

10. Matveeva A, Kovalevska L, Polischuk A, Kashuba E. The IL-2-STAT5 pathway is blocked in chronic lymphocytic leukemia cells. Oncology. 2017; 19(4): 247-53.

11. Matvieieva A, Kovalevska L, Kashuba E. The SMAD4 transcription factor shows cytoplasmic retention in B-cells of patients with chronic lymphocytic leukemia (CLL). Factors in experimental evolution of organisms. 2018; 22: 144-8.

12. Alizadeh AA, Eisen MB, Davis RE, Ma C, Lossos IS, Rosenwald A, Boldrick JC, Sabet H, Tran T, Yu X, Powell JI, Yang L, Marti GE, Moore T, Hudson J Jr, Lu L, Lewis DB, Tibshirani R, Sherlock G, Chan WC, Greiner TC, Weisenburger DD, Armitage JO, Warnke R, Levy R, Wilson W, Grever MR, Byrd $J C$, Botstein D, Brown PO, Staudt LM. Distinct types of diffuse large B-cell lymphoma identified by gene expression profiling. Nature. 2000; 403(6769):503-11.

13. Rosenwald A, Wright G, Chan WC, Connors JM, Campo E, Fisher RI, Gascoyne RD, Muller-Hermelink HK, Smeland EB, Giltnane JM, Hurt EM, Zhao H, Averett L, Yang L, Wilson WH, Jaffe ES, Simon R, Klausner RD, Powell J, Duffey PL, Longo DL, Greiner TC, Weisenburger DD, Sanger $W G$, Dave BJ, Lynch JC, Vose J, Armitage JO, Montserrat E, López-Guillermo A, Grogan TM, Miller TP, LeBlanc M, Ott G, Kvaloy S, Delabie J, Holte H, Krajci P, Stokke T, Staudt LM; Lymphoma/Leukemia Molecular Profiling Project. The use of molecular profiling to predict survival after chemotherapy for diffuse large-B-cell lymphoma. $N$ Engl J Med. 2002;346(25):1937-47. 
14. Basso K, Margolin AA, Stolovitzky G, Klein U, Dalla-Favera $R$, Califano A. Reverse engineering of regulatory networks in human B cells. Nat Genet. 2005;37(4):382-90.

15. Haferlach T, Kohlmann A, Wieczorek L, Basso G, Kronnie GT, Béné MC, De Vos J, Hernández JM, Hofmann WK, Mills KI, Gilkes A, Chiaretti S, Shurtleff SA, Kipps TJ, Rassenti LZ, Yeoh AE, Papenhausen PR, Liu WM, Williams PM, Foà R. Clinical utility of microarray-based gene expression profiling in the diagnosis and subclassification of leukemia: report from the International Microarray Innovations in Leukemia Study Group. J Clin Oncol. 2010; 28(15):2529-37.

16. Weber-Nordt RM, Egen C, Wehinger J, Ludwig W, Gouilleux-Gruart V, Mertelsmann R, Finke J. Constitutive activation of STAT proteins in primary lymphoid and myeloid leukemia cells and in Epstein-Barr virus (EBV)-related lymphoma cell lines. Blood. 1996;88(3):809-16.

17. Malin S, McManus S, Busslinger M. STAT5 in B cell development and leukemia. Curr Opin Immunol. 2010;22(2):168-76.

18. Malin S, McManus S, Cobaleda C, Novatchkova M, Delogu A, Bouillet P, Strasser A, Busslinger M. Role of STAT5 in controlling cell survival and immunoglobulin gene recombination during pro-B cell development. Nat Immunol. 2010;11(2):171-9.

19. Mitra A, Ross JA, Rodriguez G, Nagy ZS, Wilson HL, Kirken RA. Signal transducer and activator of transcription $5 \mathrm{~b}$ (Stat5b) serine 193 is a novel cytokine-induced phospho-regulatory site that is constitutively activated in primary hematopoietic malignancies. J Biol Chem. 2012;287(20): 16596-608.

20. Heltemes-Harris LM, Farrar MA. The role of STAT5 in lymphocyte development and transformation. Curr Opin Immunol. 2012;24(2):146-52.

21. Wingelhofer B, Neubauer HA, Valent P, Han X, Constantinescu SN, Gunning PT, Müller M, Moriggl $R$. Implications of STAT3 and STAT5 signaling on gene regulation and chromatin remodeling in hematopoietic cancer. Leukemia. 2018;32(8):17131726.

\section{Фактор транскрипції STAT5 у В-клітинах крові при хронічному лімфолейкозі}

А. С. Матвєєва, Л. М. Ковалевська, Т. С. Іванівська, Е. Клейн, О. В. Кашуба

Мета. Встановити причину блокування сигнального шляху IL2-STAT5 у клітинах крові хворих на хронічний ліфмолейкоз (ХЛЛ). Методи. Клітини ХЛЛ виділяли з периферичної крові пацієнтів, хворихна ХЛЛ, за допомогою центрифугування у градієнті фікол-верографін. Експресію генів STAT1-6 на рівні мРНК аналізували за допомогою бази даних Oncomine. Експресію, статус фосфорилювання і клітинну локалізацію білка STAT5 вивчали методом флуоресцентної мікроскопії з використанням специфічних антитіл. Результати. На відміну від В-клітин здорових людей, експресія білка STAT5A була низькою у клітинах хворих на ХЛЛ. Як нами було встановлено раніше, сигнальний шлях IL-2-STAT5 (JAK-STAT5) інгібовано у клітинах ХЛЛ. Нами було показано низький рівень фосфорилювання білків STAT5, або повну відсутність фосфорильованої форми протеїнів в лейкемічних клітинах. Протеїн STAT5A показує цитоплазматичну локалізацію, що вказує на відсутність у ядрі комплексів, активуючих транскрипцію генів, залежних від фактора транскрипції STAT5. Висновки. Інгибування сигнального клітинного шляху IL-2-STAT5 в клітинах крові хворих на ХЛЛ реалізується за рахунок гіпофосфорилювання протеїнів STAT5 та/або відсутності активних комплексів транскрипції STAT5A у ядрі лейкемичних клітин.

К л юч о в і с с о в а: Хронічний лімфолейкоз (ХЛЛ), В-клітини периферичної крові, STAT5, STAT5A, STAT5B, сигнальний шлях IL2-STAT5.

\section{Фактор транскрипции STAT5 в B-клетках крови при хроническом лимфолейкозе}
А. С. Матвеева, Л. Ковалевская, Т. С. Ивановская, Е. Клейн, Е. В. Кашуба

Цель. Установить причину блокирования сигнального пути IL2-STAT5 в клетках крови больных хроническим лимфолейкозом (ХЛЛ). Методы. Лейкемические клетки выделяли из периферической крови с помощью центрифугирования в градиенте плотности фиколл-ве- 
рографин. Экспрессию генов STAT1-6 на уровне мРНК анализировали с помощью базы данных Oncomine. Экспрессию, статус фосфорилирования и клеточную локализацию белка STAT5 изучали методом флуоресцентной микроскопии с использованием специфических антител. Результаты. В отличие от В-клеток здоровых людей, экспрессия белка STAT5A была низкой в клетках больных ХЛЛ. Как нами было установлено ранее, сигнальный путь IL-2-STAT5 (JAK-STAT5) ингибирован в клетках ХЛЛ. Нами был показан низкий уровень фосфорилирования белков STAT5 или полное отсутствие фосфорилированной формы протеинов в лейкемических клетках. Протеин STAT5А показывает цитоплазматическую локализацию, что указывает на отсутствие в ядре комплексов, активирующих транскрипцию генов, зависимых от фактора транскрипции STAT5. Выводы. Ингибирование сигнального клеточного пути IL-2-STAT5 в клетках кровибольных ХЛЛ происходит за счёт гипофосфорилирования белков STAT5 и/или отсутствия активных комплексов транскрипции STAT5A в ядре лейкемических клеток.

Кл юч ев ы е с л о в а: Хронический лимфолейкоз (ХЛЛ), В-клетки периферической крови, STAT5, STAT5A, STAT5B, сигнальный путь IL2-STAT5.

Received 01.10.2018 